\title{
ОСОБЛИВОСТІ ВОДООБМІННИХ ПРОЦЕСІВ НЕТРАДИЦІЙНИХ МАЛОПОШИРЕНИХ ПЛОДОВИХ РОСЛИН В УМОВАХ СТЕПОВОГО ПРИДНІПРОВ'Я ЯК КРИТЕРІЙ РОЗШИРЕННЯ АСОРТИМЕНТУ ПРОДУКЦЇ̈ З ВИСОКОЮ БІОЛОГІЧНОЮ ЦІННІСЮ
}

\author{
Ю. В. Лихолат ${ }^{1 *}$, Н. О. Хромих ${ }^{1}$, А. А. Алексєєва ${ }^{1}$, \\ Т. Ю. Лихолат ${ }^{1}$, О. А. Лихолат ${ }^{2}$, О. В. Вишнікіна ${ }^{2}$, \\ В. Р. Давидов ${ }^{1}$, Р. Є. Єфанов ${ }^{1}$, І. П. Григорюк ${ }^{3}$
}

1 - Дніпровський начіональний університет імені Олеся Гончара, м. Дніпро, Україна

2 - Університет митної справи та фінансів, м. Дніпро, Україна

3 - Начіональний університет біоресурсів та природокористування України, м. Київ, Україна

\begin{abstract}
Анотація. У степовій зоні України використання у міських фітоценозах нетрадиційних малопоширених плодових рослин останнім часом набуло широких масштабів. Проте, на території степового Придніпров'я інтродукована недостатня для промислового садівництва кількість видів, включаючи природні та гібридні види родів Chaenomeles Lindl. i Berberis L. Метою роботи було порівняння показників водного обміну в листках п'яти видів барбарисів і шести видів хеномелесів, які зростають у Ботанічному саду Дніпровського національного університету імені Олеся Гончара.
\end{abstract}

Континентальність клімату регіону може неоднаково сприятливо впливати на всі інтродуковані види рослин навіть у межах роду. Оскільки оптимальні умови росту і розвитку представників родів Chaenomeles i Berberis залежать від багатьох чинників, передусім від водного режиму, актуальним $\epsilon$ вивчення особливостей процесів водообміну рослин, який може характеризувати пристосованість цих видів до складних кліматичних умов південного сходу України.

Визначено показники інтенсивності транспірації та водного дефіциту у листках п'яти видів барбарису і шести видів хеномелесу. Установлено загальну антиоксидантну здатність плодів. Для порівняння середніх 
значень вибірок застосовували критерій достовірно значущої різниці групових середніх Тьюкі.

Реакція інтродукованих рослин родів Chaenomeles i Berberis на рівень вологи у степовому регіоні підтвердила універсальний механізм адаптації рослин до аридних умов. Оскільки для цих видів відмічений помірний водний дефіцит у посушливих умовах, що визначає їх високу стійкість до кліматичних умов степового Придніпров'я, вони можуть бути рекомендованими для інтродукції в сільськогосподарське та індивідуальне садівництво як 3 метою отримання біологічно цінної сировини для промислового виробництва функціональних продуктів, так і розширення асортименту плодової продукції для власників присадибних ділянок.

Ключові слова: водний обмін, водний дефіцит, загальна антиоксидантна здатність плодів, нетрадиційні плодові культури.

Bcmyn. Негативна дія абіотичних та біотичних чинників довкілля на фоні посушливого клімату степового Придніпров'я суттєво впливає на всі елементи екосистем: Ірунти, зокрема, девастовані [30-32], а також викликає зміни метаболізму рослинних та тваринних організмів $[4$, $6,12,16,40]$, що в решті решт негативно відбивається на здоров"ї населення [3, 20, 21].

Для збереження біологічного різноманіття і розширення спектру цінних плодових рослин у степовій зоні України інтерес викликає їх інтродукція. Крім поширення декоративних видів [14, 15], значна увага приділяється введенню нетрадиційних плодових культур, які відрізняються швидким ростом, довговічністю, щорічним рясним плодоношенням, високими смаковими та лікувально-дієтичними якостями плодів. До того ж, вони є декоративними, фітомеліоративними, медоносними та лікарськими рослинами [23, 24, 38].

Інтродукція плодових культур збагачуе різноманітність флористичного складу регіональної рослинності й одночасно створює можливість розширення сировинної бази для забезпечення потреб харчування і здоров'я людини. На сьогодні в різних регіонах Україні інтродуковані понад 400 видів плодово-ягідних рослин [14, 15, 19, 22], однак, кількість видів, що впроваджена у промислове садівництво степового Придніпров'я, є недостатньою. Плоди цих рослин мають високу поживну цінність $[1,8,13]$ та $є$ джерелом фізіологічноактивних сполук $[2,18,27,29]$, що обумовило їх багатовікове використання в традиційній медицині, а на сьогодні ставить у ряд важливих об'єктів чисельних досліджень з метою отримання сировини для створення функціональних продуктів та лікувальних засобів $[35,36]$. Завдяки здатності до біосинтезу й накопичення компонентів з антиоксидантними властивостями, вживання плодових рослин може попереджувати розвиток багатьох хвороб, спричинених 
оксидативним стресом $[5,7,9,11]$. До прикладу, з антиоксидантною здатністю фенольних сполук, що містяться у рослинах, пов'язують антиканцерогенні, антимутагенні та протизапальні ефекти, а також вплив на сигнальні шляхи метаболізму канцерогенів $[17,25,28,29]$.

У степовій зоні України інтродукція рослин з віддалених географічних територій здійснюється в Ботанічному саду Дніпровського національного університету імені Олеся Гончара упродовж багатьох років, включаючно з природними та гібридними видами родів Chaenomeles Lindl. та Berberis L. Проте, вміст фізіолого-активних речовин у плодах та інших частинах рослинного організму детермінований генетично й одночасно має високу залежність від мікрокліматичних та едафічних умов, за яких відбувався онтогенетичний розвиток плодових рослин. Під час дослідження рослинних фізіологічноактивних сполук виявлено залежність рівня їх накопичення як від властивостей рослин, так і від умов середовища. Наприклад, загальний уміст алкалоїдів у стеблах і коренях різних видів роду Berberis залежить від районів походження рослин [4]. Показано, що у рослин B. asiatica у західних Гімалаях уміст берберину був значно більшим у популяцій, що росли на невеликій висоті, і в усіх інших - вищим у коренях, ніж у стеблах. Крім того, вміст вологи та калію у грунті суттєво вплинув на вміст берберину. Це є особливо актуальним для степового Придніпров'я, де клімат має континентальні особливості i не однаково сприятливий для всіх інтродукованих видів рослин, навіть у межах роду. Оскільки оптимальні умови росту і розвитку представників родів Chaenomeles та Berberis залежать від багатьох чинників, передусім від водного режиму, нагальним є вивчення особливостей процесів водообміну рослин, який може характеризувати пристосованість цих видів до складних кліматичних умов південного сходу України.

Mema - порівняння показників водного обміну в листках п'яти видів барбарисів і шести видів хеномелесів, які зростають у Ботанічному саду Дніпровського національного університету імені Олеся Гончара.

Матеріали та методи дослідженъ. Об'єкти дослідження хеномелес катаянський (Chaenomeles cathayensis (Hemsl.) C. K. Schneid.), хеномелес японський (Ch. japonica (Thunb.) Lindl. ex Spach.), хеномелес каліфорнійський (Ch. x californica W. Clarke ex C. Weber), хеномелес пишний (C. x superba (Frahm) Rehd.), хеномелес японський вар. Маулея (Ch. japonica var. maulei (Mast.) Lavallee), хеномелес прекрасний (Ch. speciosa (Sweet.) Nakai), барбарис амурський (Berberis amurensis Rupr.), барбарис корейський (B. koreana Palib.), барбарис звичайний 
(B. vulgaris L.), барбарис канадський (B. canadensis Mill.), барбарис похилений (B. $x$ declinata Schrad.).

Показники інтенсивності транспірації та водного дефіциту у листках інтродукованих плодових рослин здійснювали за класичними методиками [3] в 30-кратній повторності. Досліди проводили протягом вегетаційного періоду. Визначали загальну антиоксидантну здатність плодів, яку виражали в мг еквівалентах аскорбінової кислоти /г d.w. [36]. Для порівняння середніх значень вибірок застосовували критерій достовірно значущої різниці групових середніх Тьюкі (Honestly Significant Difference test, або Tukey's HSD test). Критерій Тьюкі дозволяє коректно здійснювати множинні парні порівняння середніх значень. Різниця середніх визнана статистично значущою за довірчою ймовірністю $\mathrm{P} \geq 95 \%$. Розрахунок апостеріорного множинного парного критерію Тьюкі здійснено у комп'ютерному пакеті прикладних статистичних програм Statgraphics Centurion XV Version 15.1.02.

Результати та їx обговорення. Адаптація рослин до впливу сукупності екологічних чинників навколишнього середовища значною мірою визначається здатністю рослинного організму протистояти витратам води $[26,33,34,40]$.

Стресовий стан рослин, що виникає при надмірних витратах, призводить до зміни величин показників водного обміну рослинних організмів. Ступінь варіативності цих показників в несприятливих умовах водозабезпечення відображає стійкість рослинного організму. Реакція рослин на дію екстремальних умов середовища проявляється у першу чергу в змінах загального вмісту води та її форм у листках, що може характеризуватись такими показниками, як інтенсивність транспірації та рівень водного дефіциту. Відомо, що ці показники можуть збільшуватися або зменшуватися залежно від інтенсивності впливу екологічних чинників, насамперед, температури повітря та вмісту вологи в грунті $[10,37,39]$. Для досліджених об'єктів відмічені як міжродові, так і міжвидові особливості інтенсивності транспірації.

Інтенсивність транспірації суттєво коливалась у посушливий період, коли рослини недостатньо забезпечені грунтовою вологою. Спостерігалися зміни показників у межах від 46,59 мг/г (B. amurensis) до 110,31 мг/г (B. vulgaris) у представників роду Berberis L. та від $130,28 \mathrm{мг} / г$ (Ch. cathayensis) до $187,56 \mathrm{мг} / г$ (Ch. $x$ superba) у рослин роду Chaenomeles Lindl. (Табл. 1).

У посушливий період відбувається, як правило, підвищення інтенсивності освітлення, добової температури повітря та грунту, що призводить до підвищення втрати води рослинами через транспірацію. 
Данні таблиці 1 свідчать, що достовірні відмінності $(99,9 \%)$ в інтенсивності транспірації виявлені між рослинами всіх досліджених видів роду Berberis L. та більшості видів роду Chaenomeles Lindl. Виключення становила порівнювана пара видів Ch. cathayensis та Ch. japonica (менше 95\%). У вологий період вегетації для рослин роду Berberis L. характерна підвищена інтенсивність процесу транспірації. У листках рослин роду Berberis L. витрати води внаслідок транспірації змінювалися в межах від 65,48 мг/г (B. canadensis) до $177,6 \mathrm{мг} / г$ (B. vulgaris).

Таблиця 1. Інтенсивність транспірації в листках рослин родів Chaenomeles Lindl. та Berberis L. у посушливий період вегетації, мг/г за годину

Table 1. The intensity of transpiration in the plants' leaves of the genus Chaenomeles Lindl. and Berberis L. during the dry growing season, $\mathrm{mg} / \mathrm{g}$ per hour

\begin{tabular}{|c|c|c|c|c|}
\hline Вид & Середнє & $\begin{array}{l}\text { Стандартне } \\
\text { відхилення }\end{array}$ & $\begin{array}{l}\text { Коефіцієнт } \\
\text { варіації, \% }\end{array}$ & $\begin{array}{c}\text { Стандартна } \\
\text { похибка }\end{array}$ \\
\hline \multicolumn{5}{|c|}{ Рід Chaenomeles Lindl. } \\
\hline Ch. cathayensis & 130,28 & 0,160104 & 0,121031 & 0,0924 \\
\hline Ch. Japonica & 132,29 & 0,157162 & 0,118801 & 0,0907 \\
\hline Ch. $x$ californica & 151,39 & 0,155242 & 0,102544 & 0,0896 \\
\hline Ch. $x$ superba & 187,56 & 0,115902 & 0,061795 & 0,0669 \\
\hline Ch. japonica var. maulei & 168,42 & 0,164418 & 0,097626 & 0,0949 \\
\hline Ch. Spesiosa & 142,38 & 0,298161 & 0,209412 & 0,1721 \\
\hline \multicolumn{5}{|c|}{ Рід Berberis L. } \\
\hline B. $x$ declinata & 102,25 & 0,0971253 & 0,094991 & 0,0561 \\
\hline B. amurensis & 46,59 & 0,331713 & 0,711932 & 0,1915 \\
\hline B. koreana & 74,68 & 0,270555 & 0,362286 & 0,1562 \\
\hline B. vulgaris & 110,31 & 0,120554 & 0,109290 & 0,0696 \\
\hline B. canadensis & 74,37 & 0,240901 & 0,323908 & 0,1391 \\
\hline
\end{tabular}

У рослин роду Chaenomeles Lindl. інтенсивність транспірації знижувалась, виключення становили рослини виду Ch. $x$ californica. У листках рослин роду Chaenomeles Lindl. варіювали від 115,4 мг/г (Ch. japonica) до 218,12 мг/г (Ch. x californica) (Табл. 2). 
Аналіз отриманих результатів показав, що достовірні відмінності $(99,9 \%)$ в інтенсивності транспірації виявлені між більшістю видів у межах родів Berberis L. та Chaenomeles Lindl. (Табл. 2). Виключення з цієї закономірності становили порівнювані пари B. canadensis та B. koreana (менше 95\%), а також Ch. spesiosa та Ch. japonica (менше $95 \%)$.

Таблиця 2. Інтенсивність транспірації в листках рослин родів Chaenomeles Lindl. та Berberis L. у вологий період вегетації, мг/г за годину

Table 2. The intensity of transpiration in the plants' leaves of the genus Chaenomeles Lindl. and Berberis L. during the the wet growing season, $\mathrm{mg} / \mathrm{g}$ per hour

\begin{tabular}{|c|c|c|c|c|}
\hline Вид & Середнє & $\begin{array}{c}\text { Стандартне } \\
\text { відхилення }\end{array}$ & $\begin{array}{l}\text { Коефіцієнт } \\
\text { варіацї, \% }\end{array}$ & $\begin{array}{c}\text { Стандартна } \\
\text { похибка }\end{array}$ \\
\hline \multicolumn{5}{|c|}{ Рід Chaenomeles Lindl. } \\
\hline Ch. cathayensis & 119,40 & 0,196044 & 0,164187 & 0,1132 \\
\hline Ch. Japonica & 115,41 & 0,169214 & 0,146624 & 0,0977 \\
\hline Ch. $x$ californica & 218,12 & 0,112398 & 0,051529 & 0,0649 \\
\hline Ch. $x$ superba & 166,56 & 0,265393 & 0,159341 & 0,1532 \\
\hline Ch. japonica var. maulei & 158,78 & 0,207926 & 0,130955 & 0,1200 \\
\hline Ch. Spesiosa & 116,09 & 0,085049 & 0,073263 & 0,0491 \\
\hline \multicolumn{5}{|c|}{ Рід Berberis L. } \\
\hline B. $x$ declinata & 123,61 & 0,162583 & 0,131526 & 0,0939 \\
\hline B. amurensis & 136,61 & 0,217792 & 0,159430 & 0,1257 \\
\hline B. koreana & 132,55 & 0,379868 & 0,286585 & 0,2193 \\
\hline B. vulgaris & 177,64 & 0,215174 & 0,121129 & 0,1242 \\
\hline B. canadensis & 65,48 & 0,26 & 0,397068 & 0,1501 \\
\hline
\end{tabular}

Реальна небезпека водного дисбалансу в рослинному організмі виникає за високої інтенсивності транспірації у період надходження обмеженої кількості води в рослини, що найбільш виразно проявляється в умовах континентального клімату степової зони України. Якщо надмірні втрати води рослинами не поновлюються своєчасно, відбувається поступове обезводнення рослинного організму, що призводить до прояву ознак водного дефіциту, які є причиною зменшення родючості рослин та зниження якості плодів. 
У дослідженні встановлено, що за умов посухи рівень водного дефіциту варіював у межах від $11,57 \%$ (Ch. spesiosa) до 18,82\% (Ch. japonica var. maulei) у представників роду Chaenomeles Lindl. та від $14,62 \%$ (B. amurensis) до $16,16 \%$ (B. canadensis) у представників роду Berberis L. (Табл. 3).

Таблиця 3. Показники водного дефіциту в листках рослин родів Chaenomeles Lindl. та Berberis L. у посушливий період вегетації, \%

Table 3. Indicators of water deficit in the plants' leaves of the genus Chaenomeles Lindl. and Berberis L. during the dry growing season, $\%$

\begin{tabular}{|c|c|c|c|c|}
\hline Вид & Середне & $\begin{array}{l}\text { Стандартне } \\
\text { відхилення }\end{array}$ & $\begin{array}{l}\text { Коефіцієнт } \\
\text { варіації, \% }\end{array}$ & $\begin{array}{c}\text { Стандартна } \\
\text { похибка }\end{array}$ \\
\hline \multicolumn{5}{|c|}{ Рід Chaenomeles Lindl. } \\
\hline Ch. cathayensis & 15,61 & 0,3360 & 2,1525 & 0,1940 \\
\hline Ch. Japonica & 14,78 & 0,0513 & 0,347277 & 0,0296 \\
\hline Ch. $x$ californica & 13,84 & 0,0800 & 0,578035 & 0,0462 \\
\hline Ch. $x$ superba & 16,27 & 0,1652 & 1,015530 & 0,0954 \\
\hline Ch. japonica var. maulei & 18,82 & 0,1877 & 0,997196 & 0,1084 \\
\hline Ch. Spesiosa & 11,57 & 0,1266 & 1,094720 & 0,0731 \\
\hline \multicolumn{5}{|c|}{ Рід Berberis L. } \\
\hline B. $x$ declinata & 15,33 & 0,1429 & 0,932251 & 0,0825 \\
\hline B. amurensis & 14,62 & 0,0900 & 0,615595 & 0,0520 \\
\hline B. koreana & 16,14 & 0,1266 & 0,784690 & 0,0731 \\
\hline B. vulgaris & 14,85 & 0,1277 & 0,859740 & 0,0737 \\
\hline B. canadensis & 16,16 & 0,1365 & 0,844877 & 0,0788 \\
\hline
\end{tabular}

Установлено, що достовірні відмінності (99,9\%) показників водного дефіциту в листках спостерігались між усіма дослідженими видами роду Chaenomeles Lindl. (Табл. 3). Серед представників роду Berberis L. достовірні відмінності $(99,9 \%)$ були виявлені для більшості досліджуваних видів. Виключення із загальної закономірності становили порівнювана пара B. amurensis та B. vulgaris (менше 95\%), а також пара $B . x$ declinata та $B$. vulgaris, для якої встановлені відмінності на рівні достовірної ймовірності $95 \%$.

У вологий період вегетації значення водного дефіциту варіювали в межах від 6,3\% (Ch. cathayensis) до $18,2 \%$ (Ch. x superba) у рослин роду 
Chaenomeles Lindl. та від 8,1\% (B. x declinata) до 15,2\% (B. vulgaris) у листках роду Berberis L. (Табл. 4).

За результатами наших досліджень, достовірні відмінності (99,9\%) водного дефіциту виявлені між усіма видами роду Chaenomeles Lindl., крім порівнюваної пари Ch. japonica та Ch. x californica (менше 95\%), а між Ch. japonica var. maulei та Ch. spesiosa відмінності становили 95\% (Табл. 4). У межах роду Berberis L. достовірні відмінності (99,9\%) виявлені для всіх досліджуваних видів, крім порівнюваної пари видів B. $x$ declinata та B. koreana (менше 95\%).

Таблиця 4. Показники водного дефіциту в листках рослин родів Chaenomeles Lindl. та Berberis L. у вологий період вегетації, \%

Table 4. Indicators of water deficit in the plants' leaves of the genus Chaenomeles Lindl. and Berberis L. during the wet growing season, \%

\begin{tabular}{|c|c|c|c|c|}
\hline Вид & Середнє & $\begin{array}{l}\text { Стандартне } \\
\text { відхилення }\end{array}$ & $\begin{array}{l}\text { Коефіцієнт } \\
\text { варіації, \% }\end{array}$ & $\begin{array}{c}\text { Стандартна } \\
\text { похибка }\end{array}$ \\
\hline \multicolumn{5}{|c|}{ Рід Chaenomeles Lindl. } \\
\hline Ch. cathayensis & 6,33 & 0,0603 & 0,951744 & 0,0348 \\
\hline Ch. Japonica & 10,44 & 0,2875 & 2,754330 & 0,1660 \\
\hline Ch. $x$ californica & 10,36 & 0,1680 & 1,622410 & 0,0970 \\
\hline Ch. $x$ superba & 18,24 & 0,1234 & 0,676540 & 0,0713 \\
\hline Ch. japonica var. maulei & 8,81 & 0,1904 & 2,161440 & 0,1099 \\
\hline Ch. Spesiosa & 9,25 & 0,0757 & 0,818287 & 0,0437 \\
\hline \multicolumn{5}{|c|}{ Рід Berberis L. } \\
\hline B. $x$ declinata & 8,14 & 0,0854 & 1,04963 & 0,0493 \\
\hline B. amurensis & 8,81 & 0,0954 & 1,08279 & 0,0551 \\
\hline B. koreana & 8,78 & 0,0917 & 1,04387 & 0,0529 \\
\hline B. vulgaris & 15,15 & 0,1735 & 1,14517 & 0,1002 \\
\hline B. canadensis & 10,16 & 0,0551 & 0,542262 & 0,0318 \\
\hline
\end{tabular}

Для оцінки біологічної цінності плодів різних видів родів Berberis L. та Chaenomeles Lindl. з'ясували їх загальну антиоксидантну здатність за вмістом еквівалентів аскорбінової кислоти (Табл. 5). Установлено, що серед плодів рослин роду Berberis L. найвищі антиоксидантні властивості притаманні видам B. koreana та B. $x$ declinata, серед роду Chaenomeles Lindl. виділяються види C. cathayensis та C. x californica. 
Таблиця 5. Загальна антиоксидантна здатність у плодів рослин родів Chaenomeles Lindl. та Berberis L., мг еквівалентів аскорбінової кислоти /г сухої ваги

Table 5. Total antioxidant capacity in the plants' fruits of the genus Chaenomeles Lindl. and Berberis L., mg equivalents of ascorbic acid /g dry weight

\begin{tabular}{|l|c|}
\hline \multicolumn{1}{|c|}{ Вид } & $\begin{array}{c}\text { Загальна антиоксидантна здатність, мг } \\
\text { еквівалентів аскорбінової кислоти /г сухої ваги } \\
\text { Рід Berberis } \mathrm{L} .\end{array}$ \\
\hline B. vulgaris & $7.6 \pm 0.39$ \\
\hline B. amurensis & $7.1 \pm 0.54$ \\
\hline B. canadensis & $5.0 \pm 0.41$ \\
\hline B. koreana & $9.6 \pm 0.56$ \\
\hline B. x declinata & $8.6 \pm 0.50$ \\
\hline \multicolumn{2}{|c|}{ Рід Chaenomeles Lindl. } \\
\hline C. speciosa & $565.8 \pm 15.7$ \\
\hline C. cathayensis & $1121.7 \pm 27.5$ \\
\hline C. japonica & $885.6 \pm 19.5$ \\
\hline C. japonica var. maulei & $872.3 \pm 21.9$ \\
\hline C. x superba & $784.8 \pm 16.8$ \\
\hline C. x californica & $937.7 \pm 22.3$ \\
\hline
\end{tabular}

Висновки. Реакція інтродукованих видів рослин родів Chaenomeles Lindl. i Berberis L. на рівень вологи у степовому регіоні підтвердила універсальний механізм адаптації рослин до аридних умов. Оскільки для цих видів відмічений помірний водний дефіцит у посушливих умовах, що визначає їх високу стійкість до кліматичних умов степового Придніпров'я, вони можуть бути рекомендованими для інтродукції в сільськогосподарське та індивідуальне садівництво з метою отримання біологічно цінної сировини.

\section{Reference}

1. Aliakbarlu, J., Ghiasi, S., \& Bazargani-Gilani, B. (2018). Effect of extraction conditions on antioxidant activity of barberry (Berberis vulgaris L.) fruit extracts. Veterinary Research Forum, 9 (4), 361-365. https://doi.org/10.30466/vrf.2018.33090 
2. Andola, H. C., Gaira, K.S., Rawal, R. S., Rawat, M.S., \& Bhatt, I. D. (2010). Habitat-dependent variations in berberine content of Berberis asiatica Roxb. ex. DC. in Kumaon, Western Himalaya. Chemistry \& Biodiversity, 7 (2), 415-420. https://doi.org/10.1002/cbdv.200900041

3. Andrusevich, K. V., Nazarenko, M. M., Lykholat, T. Yu., \& Grigoryuk, I. P. (2018). Effect of traditional agriculture technology on communities of soil invertebrates. Ukrainian journal of Ecology, 8(1), 33-40. https://doi.org/ 10.15421/2017_184

4. Balfagón, D., Zandalinas, S. I., Baliño, P., Muriach, M., \& GómezCadenas, A. (2018). Involvement of ascorbate peroxidase and heat shock proteins on citrus tolerance to combined conditions of drought and high temperatures. Plant Physiology and Biochemistry, 127, 194199. https://doi.org/10.1016/j.plaphy.2018.03.029

5. Beecher, G. R. (2003). Overview of dietary flavonoids: nomenclature, occurrence and intake. The Journal of Nutrition, 133 (10), 3248-3254. https://doi.org/10.1093/jn/133.10.3248S

6. Blum, A. (2017). Osmotic adjustment is a prime drought stress adaptive engine in support of plant production. Plant Cell and Environment, 40, 4-10. https://doi.org/10.1111/pce.12800

7. Choudhury, F. K., Rivero, R. M., Blumwald, E., \& Mittler, R. (2017). Reactive oxygen species, abiotic stress and stress combination. The Plant Journal, 90 (5), 856-867. https://doi.org/10.1111/tpj.13299

8. Di, D. L., Liu, Y. W., Ma, Z. G., \& Jiang, S. X. (2003). Determination of four alkaloids in Berberis plants by HPLC. Zhongguo Zhong Yao Za Zhi [China Journal of Chinese Materia], 28 (12), 1132-1134.

9. Dimitrijević, M.V., Mitić, V.D., Ranković, G.Ž., \& Miladinović, D. L. (2019). Survey of antioxidant properties of barberry: a chemical and chemometric approach. Analytical Letters, 53 (5), 671-682. https://doi.org/10.1080/00032719.2019.1663862

10. Gowayed, S.M.H., Al-Zahrani, H.S. M., \& Metwali1, E. M.R. (2017). Improving the salinity tolerance in potato (Solanum tuberosum) by exogenous application of silicon dioxide nanoparticles. International journal of agriculture \& biology, $19(1)$, 183-192 https://doi.org/10.17957/IJAB/15.02

11. Guo, Y. Y., Tian, S. S., Liu, S. S., Wang, W. Q., \& Sui, N. (2018). Energy dissipation and antioxidant enzyme system protect photosystem II of 
sweet sorghum under drought stress. Photosynthetica, 56 (3), 861-872. https://doi.org/10.1007/s11099-017-0741-0

12. He, F., Sheng, M., \& Tang, M. (2017). Effects of Rhizophagus irregularis on photosynthesis and antioxidative enzymatic system in Robinia pseudoacacia L. under drought stress. Frontiers in Plant Science, 8, 183. https://doi.org/10.3389/fpls.2017.00183

13. Huang, W.Y., Cai, Y.Z., \& Zhang, Y. (2010). Natural phenolic compounds-from medicinal herbs and dietary plants: potential use for cancer prevention. Nutrition and Cancer, 62 (1), 1-20. https://doi.org/10.1080/0163558090319158

14. Klymenko, S. V., Brindza, J., \& Grygorieva, O. V. (2015). Pervaya mezhdunarodnaya nauchnaya konferentsiya na temu "Netraditsionnyie, novyie i zabyityie vidyi rasteniy: nauchnyie i prakticheskie aspektyi kultivirovaniya" [First international scientific conference "Nontraditional, new and forgotten species: scientific and practical aspects of cultivation"]. IntroduktsIya roslin [Plant Introduction], 1, 38-44. (in Russian).

15. Kohno, N.A., \& Kurdyuk, A. M. (2010). Teoreticheskie osnovyi $i$ opyit introduktsii drevesnyih rasteniy $v$ Ukraine. [Theoretical bases and experience of introduction of arboreal plants are in Ukraine]. PP Format. (in Russian).

16. Kosová, K., Vítámvás, P., Urban, M. O., Prášil, I. T., \& Renaut, J. (2018). Plant abiotic stress proteomics: the major factors determining alterations in cellular proteome. Frontiers in Plant Science, 9, 122. https://doi.org/10.3389/fpls.2018.00122

17. Laxa, M., Liebthal, M., Telman, W., Chibani, K., \& Dietz, K. J. (2019). The role of the plant antioxidant system in drought tolerance. Antioxidants, 8 (94), 1-32. https://doi.org/10.3390/antiox8040094

18. Lykholat, T. Yu., Lykholat, O. A., Marenkov, O. M., Kulbachko, Yu. L., Kovalenko, I. M., \& Didur, O. O. (2019). Xeneostrogenes influence on cholinergic regulation in female rats of different age. Ukrainian Journal of Ecology, 9 (1), 240-243.

19. Lykholat, Y.V., Khromykh, N.O., Lykholat, T.Y., Didur, O. O., Lykholat, O. A., Legostaeva, T. V., Kabar, A. M., Sklyar, T. V., Savosko, V. M., Kovalenko, I. M., Davydov, V. R., Bielyk, Yu. V., Volyanik, K. O., Onopa, A. V., Dudkina, K. A., \& Grygoryuk, I. P. (2019). Industrial characteristics and consumer properties of Chaenomeles Lindl. Fruits. Ukrainian Journal of Ecology, 9 (3). 132-137. 
20. Lykholat, Y., Khromykh, N., Didur, O., Alexeyeva, A., Lykholat, T., \& Davydov, V. (2018). Modeling the invasiveness of Ulmus pumila in urban ecosystems under climate change. Regulatory Mechanisms in Biosystems, 9 (2), 161-166. https://doi.org/10.15421/021824

21. Lykholat, Yu. V., Khromykh, N. O., \& Alexeyeva, A. A. (2019). Stan invaziinosti Ulmus Pumila L. v urboekosystemi za klimatychnykh zmin [Condition of invasiveness of Ulmus pumila L. in urboecosystem because of climatic changes]. Ekolohichnyi visnyk Kryvorizhzhia [Ecological Bulletin of Kryvyi Rih District], 4, 7-21. https://doi.org/10.31812/ecobulletin-krd.v4i0.2525 (in Ukrainian).

22. Lykholat, Yu. V., Khromykh, N. O., Ivan'ko, I. A., Matyukha, V.L., Kravets, S.S., Didur, O. O., Alexeyeva, A. A., \& Shupranova, L. V. (2017). Assessment and prediction of the invasiveness of some alien plants in conditions of climate change in the steppe Dnieper region. Biosystems Diversity, 25 (1), 52-59. https://doi.org/10.15421/011708

23. Mezhenskyi, V.M. (2004). Sklad i vykorystannia kolektsii netradytsiinykh plodovykh kultur. 1. Khenomeles (Shaenomeles Lindl.) [Composition and use of a collection of unconventional fruit crops. 1. Cenomeles]. Henetychni resursy roslyn [Genetic resources of plants], 1, 123-127. (in Ukrainian).

24. Mezhenskyi, V. M., Kostenko, N. P., Likar, S. P., \& Dushar, M. B. (2019). Rozroblennia novoi metodyky provedennia ekspertyzy sortiv yaponskoi aivy (Chaenomeles Lindl.) na vidminnist, odnoridnist ta stabilnist [Development of new guidelines for the conduct of tests for distinctness, uniformity and stability of Japanese quince (Chaenomeles Lindl.) cultivars]. Plant Varieties Studying and Protection, 15 (4), 337-353. https://doi.org/10.21498/2518-1017.15.4.2019.188507 (in Ukrainian).

25. Orhan, I. E. (2012). Current concepts on selected plant secondary metabolites with promising inhibitory effects against enzymes linked to Alzheimer's disease. Current Medicinal Chemistry, 19 (14), 2252-2261. https://doi.org/10.2174/092986712800229032

26. Petridis, A., Therios, I., Samouris, G., Koundouras, S., \& Giannakoula, A. (2012). Effect of water deficit on leaf phenolic composition, gas exchange, oxidative damage and antioxidant activity of four Greek olive (Olea europaea L.) cultivars. Plant Physiology and Biochemistry, 60, 1-11. https://doi.org/10.1016/j.plaphy.2012.07.014

27. Ros, J. M., Laencina, J., Hellin, P., Jordán, M. J., Vila, R., \& Rumpunen, K. (2004). Characterization of juice in fruits of different 
Chaenomeles species. Food Science and Technology, 37 (3), 301-307. https://doi.org/10.1016/j.lwt.2003.09.005

28. Rosalie, R., Joasc, J., Deytieux-Belleau, C., Vulcain, E., Payet, B., Dufosse, L., \& Lechaudel, M. (2015). Antioxidant and enzymatic responses to oxidative stress induced by pre-harvest water supply reduction and ripening on mango (Mangifera indica L. cv. 'Cogshall') in relation to carotenoid content. Journal of Plant Physiology, 184, 68-78. https://doi.org/10.1016/j.jplph.2015.05.019

29. Sahan, Y., Cansev, A., Celik, A., \& Cinar, A. (2012). Determination of various chemical properties, total phenolic content, antioxidant capacity and organic acids in Laurocerasus officinalisfruits. Acta Horticulturae, 939, 359-366. https://doi.org/10.17660/ActaHortic.2012.939.47

30. Savosko, V. M. (2011). Melioraciya ta fitorekultyvaciya zemel [Land melioration and phyreclamation]. Dionis. (in Ukrainian).

31. Savosko, V.M., Lykholat, Y.V., Bielyk, Yu. V., \& Lykholat, T.Y. (2019). Ecological and geological determination of the initial pedogenesis on devastated lands in the Kryvyi Rih Iron Mining \& Metallurgical District (Ukraine). Journal of Geology, Geography and Geoecology, 28 (4), 738-746. https://doi.org/10.15421/111969

32. Savosko, V., Lykholat, Yu., Domshyna, K., \& Lykholat, T. (2018). Ekolohichna ta heolohichna zumovlenist poshyrennia derev i chaharnykiv na devastovanykh zemliakh Kryvorizhzhia [Ecological and geological determination of trees and shrubs' dispersal on the devastated lands at Kryvorizhya]. Journal of Geology, Geography and Geoecology, 27 (1), 116-130. https://doi.org/10.15421/111837 (in Ukrainian).

33. Suzuki, N., Rivero, R. M., Shulaev, V., Blumwald, E., \& Mittler, R. (2014). Abiotic and biotic stress combinations. New Phytologist, 203, 32-43. https://doi.org/10.1111/nph.12797

34. Tschaplinski, T. J., Abraham, P. E., Jawdy, S. S., Gunter, L. E., Martin, M. Z., Engle, N. L., Yang, X., \& Tuskan, G. A. (2019). The nature of the progression of drought stress drives differential metabolomic responses in Populus deltoids. Annals of Botany, 124 (4), 617-626. https://doi.org/10.1093/aob/mcz002

35. Vrhovsek, U., Rigo, A., Tonon, D., \& Mattivi, F. (2004). Quantitation of polyphenols in different apple varieties. Journal of Agricultural and Food Chemistry, 52 (21), 6532-6538. https://doi.org/10.1021/jf049317z 
36. Zaitseva, I. O., \& Dolhova, L. H. (2010). Fizioloho-biokhimichni osnovy introduktsii derevnykh roslyn u stepovomu Prydniprovi [Physiological and biochemical foundations of the introduction of woody plants in the Steppe Dnieper]. Publishing House Dnipropetrovsk National University. (in Ukrainian).

37. Zandalinas, S. I., Balfagón, D., Arbona, V., \& Gómez-Cadenas, A. (2017). Modulation of antioxidant defense system is associated with combined drought and heat stress tolerance in Citrus. Frontiers in Plant Science, 8, 953. https://doi.org/10.3389/fpls.2017.00953

38. Zandalinas, S. I., Mittler, R., Balfagón, D., Arbona, V., \& GómezCadenas, A. (2018). Plant adaptations to the combination of drought and high temperatures. Physiologia Plantarum, 62 (1), 2-12. https://doi.org/10.1111/ppl.12540

39. Zhang, H., Ni, Z., Chen, Q., Guo, Z., Gao, W., Su, X., \& Qu, Y. (2016). Proteomic responses of drought-tolerant and drought-sensitive cotton varieties to drought stress. Molecular \& General Genetics, 291 (3), 1293-303. https://doi.org/10.1007/s00438-016-1188-x

40. Zhang, J. Y., Cruz de Carvalho, M.H., Torres-Jerez, I., Kang, Y., Allen, S. N., Huhman, D. V., Tang, Y., Murray, J., Sumner, L. W., \& Udvardi, M.K. (2014). Global reprogramming of transcription and metabolism in Medicago truncatula during progressive drought and after rewatering. Plant, Cell \& Environment, 37 (11), 2553-2576. https://doi.org/10.1111/pce.12328

\section{PECULIARITIES OF WATER EXCHANGE PROCESSES OF NON-TRADITIONAL LOW-WIDE FRUIT PLANTS IN CONDITIONS STEP PRYDNIPROVYA AS THE CRITERIA FOR PRODUCT WITH HIGH BIOLOGICAL VALUE EXTENSION}

Yu. V. Lykholat ${ }^{1}$, N. O. Khromykh ${ }^{1}$, A. A. Alexeeva ${ }^{1}$, T. Y. Lykholat $^{1}$, O. A. Lykholat ${ }^{2}$, O. V. Vishnikina ${ }^{2}$, V. R. Davydov ${ }^{1}$, R. Ye. Yefanov ${ }^{1}$, I. P. Grygoryuk ${ }^{3}$

1 - Oles Honchar Dnipro National University, Dnipro, Ukraine

2 - University of Customs and Finance, Dnipro, Ukraine

3 - National University of Life and Environmental Sciences of Ukraine, Kyiv, Ukraine

Abstract. In the steppe zone of Ukraine, the use of unconventional lowabundant fruit plants in urban phytocenoses has recently become widespread. However, a small number of species, including natural and hybrid species of the Chaenomeles Lindl and Berberis L. genera have been introduced in the steppe Prydniprovya region. The continental climate of the region may have an 
unequally favorable effect on all introduced plant species, even within the genus. Since the optimal conditions for growth and development of Chaenomeles and Berberis species depend on many factors, first of all, the water regime, it is important to study the features of plant water exchange processes that can characterize the adaptation of these species to the difficult climatic conditions of southeastern Ukraine.

The rates of transpiration and water deficiency in leaves of five species of barberry and six species of henomeles were determined. The total antioxidant capacity of the fruit was also determined. To compare sample averages, the criterion of a significantly significant difference in Tukey's group averages was used. The response of introduced plants of the Chaenomeles and Berberis genera to the moisture level in the steppe region confirmed the plant universal adaptive mechanism to arid conditions. As these species are characterized by moderate water deficit in arid conditions, which determines their high resistance to the climatic conditions of the Steppe Prydniprovya, they may be recommended for introduction into agricultural and individual gardening for the purpose of obtaining biologically valuable raw materials for industrial production of functional products and expanding the range of fruit products for homeowners.

In general, the reaction of introduced plant species of the genus Chaenomeles Lindl. and Berberis L. on the level of moisture in the steppe region confirmed the universal mechanism of adaptation of plants to arid conditions. As these species have a moderate water deficit in arid conditions, which determines their high resistance to the climatic conditions of the Steppe Prydniprovya, they can be recommended for introduction into agricultural and individual horticulture in order to obtain biologically valuable raw materials.

Keywords: water exchange, water deficiency, general antioxidant capacity of fruits, unconventional fruit crops.

\section{Citation as:}

Lykholat, Yu. V., Khromykh, N. O., Alexeeva, A. A., Lykholat, T. Y., Lykholat, O. A., Vishnikina, O. V., Davydov, V.R., Yefanov, R. Ye., \& Grygoryuk, I.P. (2020). Osoblyvosti vodoobminnykh protsesiv netradytsiinykh maloposhyrenykh plodovykh roslyn v umovakh Stepovoho Prydniprovia yak kryterii rozshyrennia APA asortymentu produktsii $\mathrm{z}$ vysokoiu biolohichnoiu tsinnistiu [Peculiarities of water exchange processes of non-traditional lowwide fruit plants in conditions Step Prydniprovya as the criteria for product with high biological value extension]. Ekolohichnyi visnyk Kryvorizhzhia [Ecological Bulletin of Kryvyi Rih District], 5, 112-126. https://doi.org/10.31812/eco-bulletin-krd.v5i0.4358

Лихолат Ю.В., Хромих Н.О., Алексєєва А.А., Лихолат Т. Ю., Лихолат О.А., Вишнікіна О.В., Давидов В.Р., Єфанов P.Є., Григорюк І.П. Особливості водообмінних процесів нетрадиційних малопоширених плодових рослин в умовах

Степового Придніпров'я як критерій розширення асортименту продукції з високою біологічною цінністю. Екологічний Вісник Криворіжж.я. 2020. Вип. 5. С. 112-126. 